\title{
Exploration and Application of CDIO Teaching Mode in Integrated English Teaching
}

\author{
XIAO Wenwen, ZHANG Baoguo \\ Leshan Normal University, Leshan, China
}

\begin{abstract}
CDIO (Conceive-Design-Implement-Operate) is one of the great engineering education reform achievements. This approach is always adopted in education of science and engineering. This paper proves that this approach also can be adopted in the language teaching. The modern society has higher requirements on the graduates of English major: basic knowledge as well as the practical abilities. Integrated English is one important course for the freshmen and sophomores of English major. The CDIO teaching mode in Integrated English teaching can cultivate the students' ability in many aspects.
\end{abstract}

Keywords: CDIO teaching mode, Integrated English, teaching, abilities

\section{Introduction}

In present China, on one side, some undergraduates are willing to choose English as their major; on the other, it's hard for the English major graduates to find the satisfactory work. For English major graduates, they are required to possess the professional English knowledge, the abilities of listening, speaking, reading, writing, and translating, as well as other skills related to the future job. As one of the main courses for English major undergraduates, Integrated English enjoys the features of lasting for four semesters and six periods per week (taking Leshan Normal University as an example). The teachers of Integrated English also try to adopt and combine different teaching methods to improve students' abilities in different aspects and continuously carry out the course reform. However, few teachers try to apply the CDIO teaching mode to the Integrated English teaching, and the implementation process and achievements are not so perfect.

\section{CDIO Teaching Mode}

The CDIO teaching mode refers to the process of Conceive-Design-Implement-Operate, and it is a kind of engineering education concept established through the exploration, research, and practice of Massachusetts Institute of Technology, Royal Institute of Technology, and other two universities. Taking the whole life span of the product as the carrier: from the conception, research and development, operation, discard to recycle, this teaching mode refers to leading the student to learn in the active and practical way of grasping the organic connection in the course, as well as improving their abilities in different aspects, such as scientific and technical knowledge, lifelong learning ability, interpersonal communication skill, teamwork spirit, and the ability to

Acknowledgements: This research is financed by the following program: Education and Teaching Reform Research Program, Leshan Normal University, Program No. JG2015-YB10.

XIAO Wenwen, master, lecturer, School of Foreign Languages, Leshan Normal University, Leshan, China.

ZHANG Baoguo, master, lecturer, School of Foreign Languages, Leshan Normal University, Leshan, China. 
construct product, process, and system in the certain environment of society and enterprise.

The CDIO teaching mode is one effective teaching mode to comprehensively cultivate the students' comprehensive quality and vocational skills based on the project (Wu, 2012). It is the integrated approach, which can be used to establish students' requirements for learning and establish the process of learning experience, carry out the effective education according to the curriculum plan, promote students' interest, and meet the requirements of cultivating the abilities and attitude of the preparatory engineers ( $\mathrm{Gu}$, Shen, \& Lu, 2009). During the teaching process, the project can combine theory with the practical skills together, in order to improve the students' ability of operating, problems analyzing and solving (Yin, Liang, \& Feng, 2013).

In 2006, Shantou University attended the Second International CDIO Conference and officially become one member of the CDIO International Cooperation Organization (Gu et al., 2012), firstly introducing the CDIO teaching mode to China. It applied the CDIO teaching mode to its teaching reform, and then some other universities take part in this activity. At the very beginning, the CDIO teaching mode was mainly applied to the courses of engineering and practice, and now more and more liberal-arts curricula teachers try to apply this mode to their teaching. English major teaching covers two skills at least: linguistic skills and vocational skills, and the interdisciplinary nature of the project-based teaching mode can realize the breakthrough of foreign language teaching reform (Zhu, 2001). Applying the CDIO teaching mode in English teaching and carrying out the project-based learning can shift the focus of the class from the teacher to the students, and cultivate the self-learning ability and practical language skills of the students.

\section{Basic Situation of Integrated English}

Integrated English is one basic compulsory course for freshmen and sophomores. Compared with other courses, Integrated English is the course to cultivate the students' professional practice ability (Tang, 2009, p. 49). This course requires its teachers to comprehensively improve the students' ability of listening, speaking, reading, writing, and translating. In Leshan Normal University, this course is arranged for freshmen and sophomores of English major and translation major, six periods each week, lasting for four semesters.

According to The Teaching Syllabus for English Majors in Higher Education (2000, pp. 4-5), the first two years of the college is the basic stage, and the main task for freshmen and sophomores is learning the basic English knowledge, accepting comprehensive and strict training of basic skills, cultivating their practical abilities of English, establishing favorable learning atmosphere, and grasping proper and effective learning methods.

Compared with other teaching methods, the CDIO teaching mode enjoys its unique features. For example, the communicative teaching method combines the knowledge of linguistics and psychology, follows the student-oriented principle, and makes the students learn in different situations. But its disadvantage lies in that it mainly focuses on the language applying abilities, and to some extent ignores the improvement of other abilities. The CDIO teaching mode can not only cultivate the language applying abilities, but also improve their abilities of self-learning and problems solving. The task-based teaching method is widely-accepted to arouse the students' interest through finishing different tasks, with lower difficulty and limited abilities covered. The CDIO teaching mode provides higher requirements for the students, cultivating their comprehensive abilities.

\section{Application of CDIO in Integrated English}

Based on different projects, the CDIO teaching mode can make the students understand and grasp the 
knowledge and skills required for this course, experience the hard work and fun of innovation and teamwork, and cultivate the comprehensive abilities related to practice (Deng, Tan, \& Mo, 2010, p. 91). Different from the courses of science and engineering, if the CDIO teaching mode is adopted in the courses of liberal arts, the teachers should adopt proper adjustments. Taking one project of "Their Circles" in Integrated English 4 as an example (with the textbook of Contemporary College English 4, Second Edition, 2012, edited by Yang Limin and published by Foreign Language Teaching and Research Press), the author will explain how to apply the CDIO teaching mode in the course of Integrated English in detail.

\section{Conceive}

In Integrated English, conceiving mainly refers to an overall arrangement of this project. For this project, in class, the teacher clarifies the detailed requirements and time to check the project result. Each group is asked to create Circles for one philosopher (Aristotle, Plato, Socrates, Confucius, Laozi, and Mencius). After class, the group leader should hold a meeting to discuss with the members on the final achievement form, for example, Circles, QQ, Weibo, and so on. Then make the project plan, to clearly mark the time and requirements of each sub-project and the labor division at each stage.

\section{Design/Prepare}

This step can be adapted into Preparation. During the process of the projects, in class, the teacher helps the students to understand the text and solve the problems in text learning; after class, according to the labor division in the group, each student collects related information or acquires related skills. Meanwhile, each group should fill in the project enforcement table.

For this step in the project of "Their Circles", in class, the teacher leads the students to learn Unit 1 (Thinking as a Hobby) and Unit 3 (Groundless Beliefs) in a cooperative way. After class, the group leader asks the members to divide the project in details and then analyze all the sub-projects. This project can be divided into the following ones: the philosophical thoughts of Aristotle (or another philosopher); analysis of his social relationship, skills related to Wechat, and Circles of Aristotle. After clarifying the detailed requirements of each sub-project, the group members try their best to finish their own parts.

\section{Implement}

This process refers to changing the materials and available information collected by the group members into the final presentation form. In this process, a meeting is also required among all the group members to show their own opinions and discuss with each other to achieve the consensus on the final presentation.

For this project, in class, the teacher helps the students to solve the still existing problems which cannot be solved through the cooperative learning within their own group and among different groups. After class, the group members hold a meeting to summarize, modify, and perfect it.

\section{Operate}

This step refers to presenting the group achievements in class. Meanwhile, each group also shows their project plan, enforcement table as well as the materials and information checked and searched during their preparation.

After this step, there is another one added: Evaluation. The teacher always adopts the following three ways for evaluation:

(1) Evaluation within group. After each group is finished, the group leader organizes the members to 
evaluate and summarize their own performance during this project.

(2) Evaluation among different groups. When one group makes their final presentation, other groups make a discussion on this and fill in the project evaluation sheet.

(3) The teacher's evaluation. The teacher makes the evaluation of each group, and tells them how to improve next time. Only in this way can the students get developed and improved in next project.

The Conceive-Design-Implement-Operate mode is regarded as the life cycle model of product, process, and system in the CDIO teaching mode. This model is mainly targeted at the projects of engineering type, so for the Integrated English teaching, the project cycle model under the CDIO teaching mode should be adjusted slightly and the arrangements in and after class are as follows:

Table 1

CDIO in Integrated English

\begin{tabular}{|l|l|l|l|l|l|}
\hline \multirow{2}{*}{ C-conceive } & In class & Get information & Determine the requirements & & \\
\cline { 2 - 6 } & After class & Make group discussion & Arrange the labor division & $\begin{array}{l}\text { Predict the } \\
\text { achievement }\end{array}$ & Make a plan \\
\hline \multirow{2}{*}{$\begin{array}{l}\text { D-design/ } \\
\text { prepare (P) }\end{array}$} & In class & Study independently & Cooperate to research & & \\
\cline { 2 - 6 } I-implement & After class & Sub-divide the project & Analyze the sub-projects & Process data & Learn related technique \\
\cline { 2 - 6 } & An class & Actively participate & Be guided by the teacher & & \\
\hline \multirow{2}{*}{ O-operate } & In class & Solve the problem & $\begin{array}{l}\text { Present the achievement in } \\
\text { class }\end{array}$ & Present the achievement \\
\cline { 2 - 6 } & After class & Practice the presentation & Evaluate within each group & $\begin{array}{l}\text { Evaluate other } \\
\text { groups }\end{array}$ & $\begin{array}{l}\text { Be evaluated by the } \\
\text { teacher }\end{array}$ \\
\hline
\end{tabular}

After receiving one-year teaching of the CDIO teaching mode in Integrated English, the students accepted the corresponding questionnaire. More than 90 students took part in the questionnaire and finally 75 of the answered questionnaires are effective, and the results are as follows:

Table 2

For the Question: Can You Accept the CDIO Teaching Mode

\begin{tabular}{lll}
\hline Choices & Students amount & Proportion \\
\hline Totally & 32 & $42.7 \%$ \\
Basically & 38 & $50.7 \%$ \\
It's difficult but acceptable & 4 & $5.3 \%$ \\
Totally not & 1 & $1.4 \%$ \\
\hline
\end{tabular}

It can be seen that most students can accept the CDIO teaching mode, and only one is not willing to accept such teaching mode.

Table 3

Your Attitude Towards the Projects

\begin{tabular}{lll}
\hline Choices & Students amount & Proportion \\
\hline I'm forced to do so. & 2 & $2.7 \%$ \\
I'm active to solve the problems. & 34 & $45.3 \%$ \\
I'm active and enthusiastic to participate. & 33 & $44 \%$ \\
It's too difficult to me. & 0 & $0 \%$ \\
I don't worry at all for there is the group leader. & 6 & $8 \%$ \\
\hline
\end{tabular}


Most students can actively and enthusiastically participate in each project, but there are still several students who thought that the group leader could shoulder the whole responsibility for them.

Table 4

Group Cooperation During the Process of Each Project

\begin{tabular}{lll}
\hline Choices & Students amount & Proportion \\
\hline Very good. Each group member can actively participate. & 10 & $13.3 \%$ \\
Good. Most group members can actively participate. & 45 & $60 \%$ \\
Just so so. Basically finished. & 20 & $26.7 \%$ \\
Bad. Mainly completed by the group leader or several members. & 0 & $0 \%$ \\
\hline
\end{tabular}

It can be seen that most students are satisfied with their cooperation, but still some of them are not so satisfied.

Table 5

After Completing the Projects

\begin{tabular}{lll}
\hline Choices & Students amount & Proportion \\
\hline Realize my own potential and feel hopeful for my future job. & 14 & $18.7 \%$ \\
See my deficiencies and clarify my learning objectives. & 53 & $70.7 \%$ \\
Experience its difficulties and refuse to participate next time. & 1 & $1.3 \%$ \\
See the gap with others and fear for the future. & 7 & $9.3 \%$ \\
\hline
\end{tabular}

The aim of adopting the CDIO teaching mode is to make the students get prepared for their future job, and most students can realize their deficiencies during the process of the project and clarify their own learning objectives.

Table 6

During the College Years, I Want to Improve the Following Abilities (Multiple)

\begin{tabular}{lll}
\hline Choices & Students amount & Proportion \\
\hline Self-learning ability & 62 & $82.7 \%$ \\
Professional knowledge & 68 & $90.7 \%$ \\
Relative employability & 47 & $62.7 \%$ \\
Ability to find and solve problems & 54 & $72 \%$ \\
Critical thinking ability & 53 & $70.7 \%$ \\
Innovation ability & 47 & $62.7 \%$ \\
Team work and communication & 54 & $72 \%$ \\
\hline
\end{tabular}

Besides the professional knowledge, most students also want to get improved in self-learning ability, professional knowledge, relative employability, ability to find and solve problems, critical thinking ability, innovation ability as well as team work and communication. 
Table 7

After Receiving One-Year Teaching Under the CDIO Teaching Mode, I Get Improved in the Following Abilities (Multiple)

\begin{tabular}{lll}
\hline Choices & Students amount & Proportion \\
\hline Self-learning ability & 43 & $57.3 \%$ \\
Professional knowledge & 30 & $40 \%$ \\
Relative employability & 17 & $22.7 \%$ \\
Ability to find and solve problems & 56 & $74.7 \%$ \\
Critical thinking ability & 24 & $32 \%$ \\
Innovation ability & 33 & $44 \%$ \\
Team work and communication & 56 & $74.7 \%$ \\
\hline
\end{tabular}

These abilities can be improved to some extent, and most students think their problem finding and solving ability and team work have been improved.

Through this questionnaire, it can be seen that most students can accept the CDIO teaching mode, and actively take part in the projects designed for each group or the whole class, cultivate their potential, realize their deficiencies through the projects enforcement, and improve their abilities on their major and future job.

However, through the questionnaire and the teaching practice, it can be seen that now it is not so satisfactory, for there are many factors to consider and it should be adjusted according to different classes, textbooks, and project. For some difficult projects, more time should be reserved for the students; some students want to keep the same group members within one semester and others want to communicate and cooperate with different group members; At the very beginning, few students feel that the group leader or some active members can shoulder the whole responsibility, so they take part in the project passively. The rotational responsibility system should be adopted for these groups. For the projects arrangement the teacher can invite the students to give some suggestions at the beginning of one semester, making the students really takeg part in the projects setting and course arrangement, and they will have higher sense of participation. Adopting the CDIO teaching mode has higher demands of the teachers, who should be not only the teachers of English, but also the teachers of technical guidance, debate, and speech. Although it's really difficult to follow this practice, it can benefit both teachers and students. Moreover, in order to apply the CDIO teaching mode to the course of Integrated English in a better way, there are still some factors to be considered and improved in the future teaching.

\section{Conclusion}

Based on the teaching practice of applying the CDIO teaching mode to the course of Integrated English, this paper analyzes how to arrange the course according to this mode and what aspects should be paid attention to when the project is carried out. The life cycle model suitable for the projects related to language learning is given in this paper through adjusting the life cycle model of the science and engineering. The teaching practice proves that the CDIO can be applied to the Integrated English for the English major. However, the teachers should not indiscriminately copy its application in the courses of science and engineering, and they should adjust it according to the content and the students' features. Only in this way, through the teaching of Integrated English, can we make the students acquire the linguistic knowledge of Integrated English and improve their future employability and realize comprehensive development. No course teaching can just adopt one teaching way, and only the combination of traditional and modern teaching ways can achieve the effective teaching. In 
the future, the author will continue to explore how to combine different kinds of teaching modes to improve her own teaching ability and further the students' development.

\section{References}

Deng, Z. J., Tan, X. L., \& Mo, H. Y. (2010). Teaching practice and research on project-based teaching mode. Journal of Hunan Engineering College, (3), 91-93.

English Group of the Teaching Guiding Committee for College Foreign Language Majors. (2000). The teaching syllabus for English majors in higher education. Beijing: Foreign Language Teaching and Research Press.

Gu, P. H., Bao, N. S., Kang, Q. L., Lu, X. H., Xiong, G. J., Lin, P., Chen, Y. (2012). CDIO in China (Volume 1). Higher Engineering Education Research, (3), 24-40.

Gu, P. H., Shen, M. F., \& Lu, X. H. (Eds. and Trans.). (2008). CDIO syllabus and standards. Shantou: Shantou University Press.

Gu, P. H., Shen, M. F., \& Lu, X. H. (Trans.). (2009). Re-understanding engineering education-international CDIO cultivating mode and method. Beijing: Higher Education Press.

Tang, H. J. (2009). On cultivating the professional practical abilities of college students in "Fundamental English". Shandong Foreign Language Teaching, (4), 49-53.

Wu, Y. L. (2012). Theoretical and practical research of the project-based teaching mode. Journal of Zhaoqing College, (4), 93-97.

Yang, L. M. (Ed.). (2012). Contemporary college English 4 (2nd ed.). Beijing: Foreign Language Teaching and Research Press.

Yang, Y. (2011). Application of CDIO teaching mode in intensive reading for English major. Journal of Tianjin Institute of Education and Science, (5), 95-96.

Yin, M., Liang, M. Y., \& Feng, J. (2013). Practice research on teaching combined with project-based method and discussion method. Education Research Frontier, (4), 184-187.

Zhu, F. (2001). Research on project-based teaching mode in China-talking about the applicability of project-based teaching mode in China's foreign language teaching. Educational Theory and Practice, (9), 54-56. 